\title{
A new species of Caprella (Crustacea: Amphipoda) from the Mediterranean Sea
}

\author{
N. Sturaro · J. M. Guerra-García
}

Received: 11 November 2010 / Revised: 16 January 2011 / Accepted: 18 January 2011 / Published online: 4 February 2011

(C) Springer-Verlag and AWI 2011

\begin{abstract}
A new caprellid amphipod, Caprella tavolarensis $\mathrm{n}$. sp., is described based on specimens collected from a Posidonia oceanica seagrass meadow at the TavolaraPunta Coda Cavallo Marine Protected Area (Sardinia, Mediterranean Sea). The species is close to Caprella liparotensis, but can be clearly distinguished by smaller size, presence of a short rostrum, body elongate and dorsally smooth, absence of serrate carina on the basis of gnathopod 2 and pereopods, mouthparts scarcely setose, absence of fine setae on peduncle of antenna 1 and absence of swimming setae on antenna 2. The number of caprellid species reported from the Mediterranean Sea has increased from 23 (1993) to 41 (2010), consequently, further taxonomical studies should be addressed to properly estimate the total amphipod diversity in the Mediterranean Sea.
\end{abstract}

Keywords Amphipoda $\cdot$ Caprellidae $\cdot$ New species · Marine protected area $\cdot$ Posidonia oceanica .

Mediterranean Sea

Communicated by H.-D. Franke.

N. Sturaro $(\square)$

Laboratoire d'Océanologie,

Département des Sciences et Gestion de l'Environnement,

Faculté des Sciences, Université de Liège, Allée de la Chimie 3,

Sart Tilman B6c, 4000 Liège, Belgium

e-mail: nicolas.sturaro@ulg.ac.be

J. M. Guerra-García

Laboratorio de Biología Marina,

Departamento de Fisiología y Zoología, Facultad de Biología,

Universidad de Sevilla, Avda. Reina Mercedes 6,

41012 Sevilla, Spain

e-mail: jmguerra@us.es

\section{Introduction}

Seagrasses are distributed worldwide $\left(600.000 \mathrm{~km}^{2}\right.$ of the marine bottoms are covered by these spermatophytes) and play an important role in the general coastal dynamics and biology (Larkum et al. 1989; Templado 2004; González et al. 2008). When compared with neighbouring areas, the meadows reveal higher abundances and species richness (Edgar et al. 1994). The main factors contributing to this improvement in biodiversity are availability of microhabitat, protection from predators, trophic resources, sediment settling, hydrodynamic force reduction (see Pranovi et al. 2000). Seagrass beds of the temperate zone support large numbers of invertebrate species and individuals, thereby providing abundant food for fishes, compared to adjacent unvegetated areas (Nakamura and Sano 2005). Along the coasts of the Mediterranean Sea, five species occur: Posidonia oceanica (Linnaeus) Delile, Zostera marina Linnaeus, Zostera noltii Hornemann, Cymodocea nodosa (Ucria) Ascherson and a lessepsian species Halophila stipulacea (Forsskål) Ascherson (Buia et al. 2000). In spite of the abundance of these seagrass meadows in the Mediterranean, caprellid communities associated to these plants have been scarcely studied, and the only records of caprellids from these habitats come from general faunistic or ecological studies (see González et al. 2008).

As a part of a general project assessing the effects of protection status (totally, partially and non protected areas) on amphipod communities associated to Posidonia oceanica beds along the Sardinian coast (Italy), several specimens of the genus Caprella were collected. Detailed examination revealed that these specimens belonged to a new species close to Caprella liparotensis, here described as Caprella tavolarensis $\mathrm{n} . \mathrm{sp}$. 
Fig. 1 Study area showing the sampling site in the TavolaraPunta Coda Cavallo Marine Protected Area (Sardinia, Mediterranean Sea) Zone A (integral reserve), zone $B$ (general reserve) and zone $C$ (partial reserve) are shown

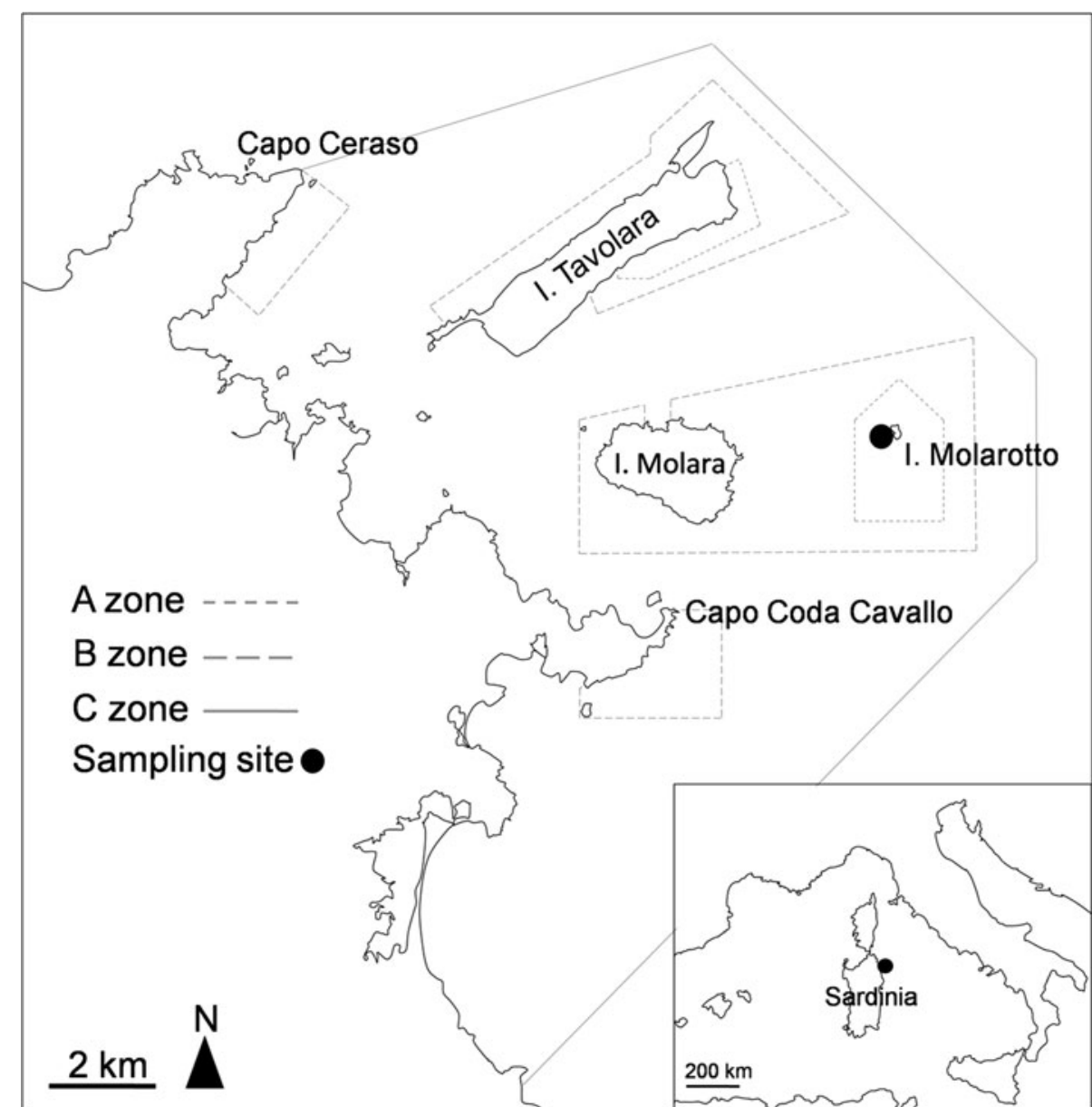

\section{Materials and methods}

The sampling was conducted at Molarotto island, an integral reserve area located at the Tavolara-Punta Coda Cavallo Marine Protected Area, NE Sardinia, Italy (Fig. 1). Samples were collected from Posidonia oceanica bed (10-15 $\mathrm{m})$ by SCUBA diving using an airlift sampler and light traps (about methods see Michel et al. 2010). The samples were sieved through a $0.5-\mathrm{mm}$ mesh and fixed in formalin $4 \%$, then transferred to $70 \%$ ethanol. Selected specimens were dissected under a Leica dissecting microscope. Appendages of selected specimens were mounted in polyvinyl-lactophenol and camera lucida drawings were made using a Leica compound microscope.

Although the phylogeny and higher classification of the caprellids are still under debate (see Laubitz 1993; Takeuchi 1993; Ito et al. 2008), Myers and Lowry (2003) have recently proposed a new phylogeny and classification for the suborder Corophiidea Leach, 1814. Based on the hypothesis of the evolution of different feeding strategies, the Corophiidea are divided into two infraorders, the Corophiida and the Caprellida. In their new classification, the superfamily Caprelloidea contains five families: Caprellidae, Caprogammaridae, Cyamidae, Dulichiidae and Podoceridae. The Caprellidae are subdivided into three subfamilies: Caprellinae, Paracercopinae and Phtisicinae. In the present paper, we have adopted the classification of Myers and Lowry (2003) considering the family Caprellidae, and the subfamily Caprellinae.

The symbols used in the present work are: A1, $2=$ Antenna 1, 2; UL = Upper lip; LL = Lower lip; LMd = Left mandible; $\mathrm{RMd}=$ Right mandible $;$ Mx 1, $2=$ Maxilla 1, $2 ;$ Mxp $=$ Maxilliped; Gn 1, $2=$ Gnathopod 1, 2; P5-7 = Pereopod 5-7; $\mathrm{Ab}=$ Abdomen. All the type material is deposited in the Museo di Storia Naturale di Verona, Italy (MVR).

\section{Results}

Family Caprellidae Leach, 1814

Subfamily Caprellinae Leach, 1814

Caprella tavolarensis n. sp. (Figs. 2, 3, 4, 5, 6, 7, 8, 9)

Type material Holotype male (used for drawings) (MVRCr 500.0). Paratype female (used for drawings) 


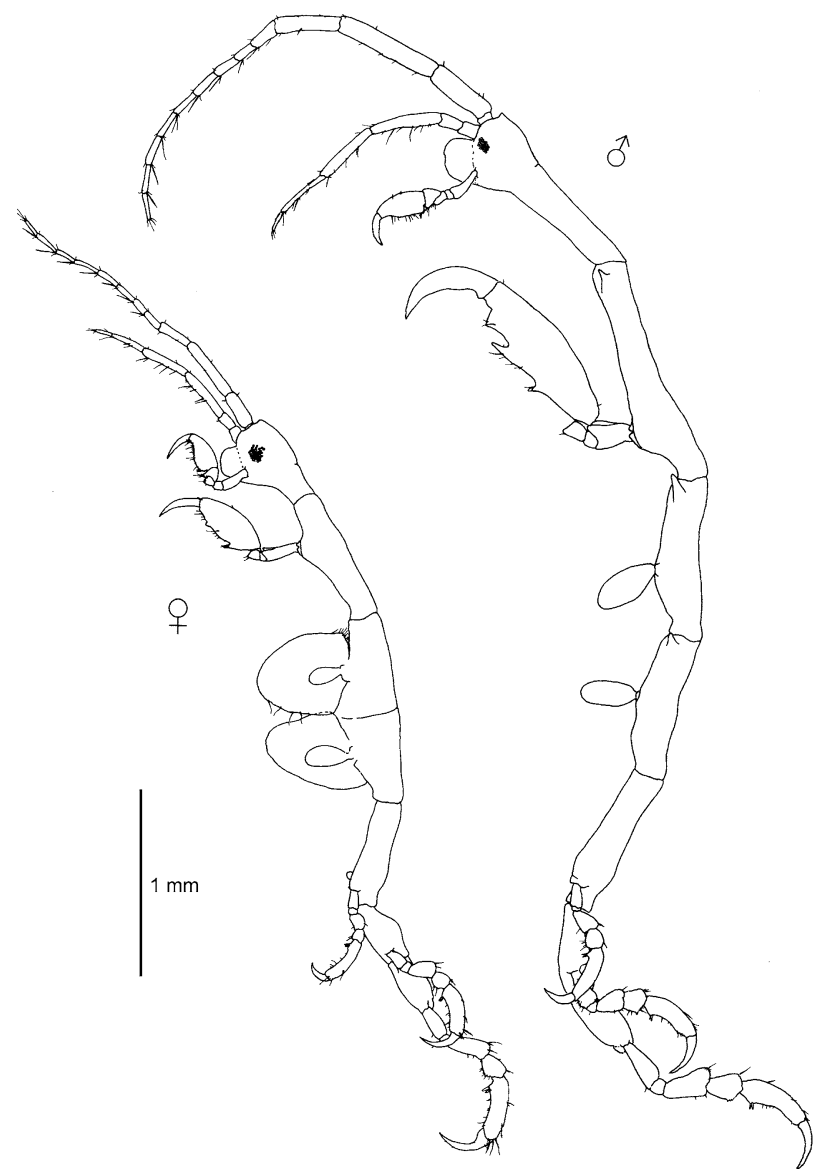

Fig. 2 Caprella tavolarensis $\mathrm{n}$. sp. Lateral view of holotype male (MVRCr 500.0) and paratype female (MVRCr 500.1)

(MVRCr 500.1). Paratypes dissected (used for drawing the mouthparts) (3 males and 3 females, MVRCr 500.2-500.7). Other paratypes ( 10 males, 8 females, 2 juveniles, MVRCr 500.8). All the material was collected from the type locality (July-August 2008).

Additional material examined 17 males, 13 females, 2 juveniles, collected from the type locality (July-August 2007)

Type locality All the material has been collected from a Posidonia oceanica meadow between 10 and $15 \mathrm{~m}$ depth at the Tavolara-Punta Coda Cavallo Marine Protected Area, A zone of Molarotto island $\left(40^{\circ} 52^{\prime} 25^{\prime \prime} \mathrm{N}, 9^{\circ} 46^{\prime} 35^{\prime \prime} \mathrm{E}\right), \mathrm{NE}$ Sardinia, Italy (Fig. 1).

Etymology The specific name refers to the area where the species was found.

Diagnosis Head with very short rostrum. Pereonites 2, 3 and 4 with anterolateral projections. Body dorsally smooth. Peduncular articles of antenna 1 not setose. Antenna 2 without swimming setae. Basis of gnathopod 2 without serrated carina but with inner projection.

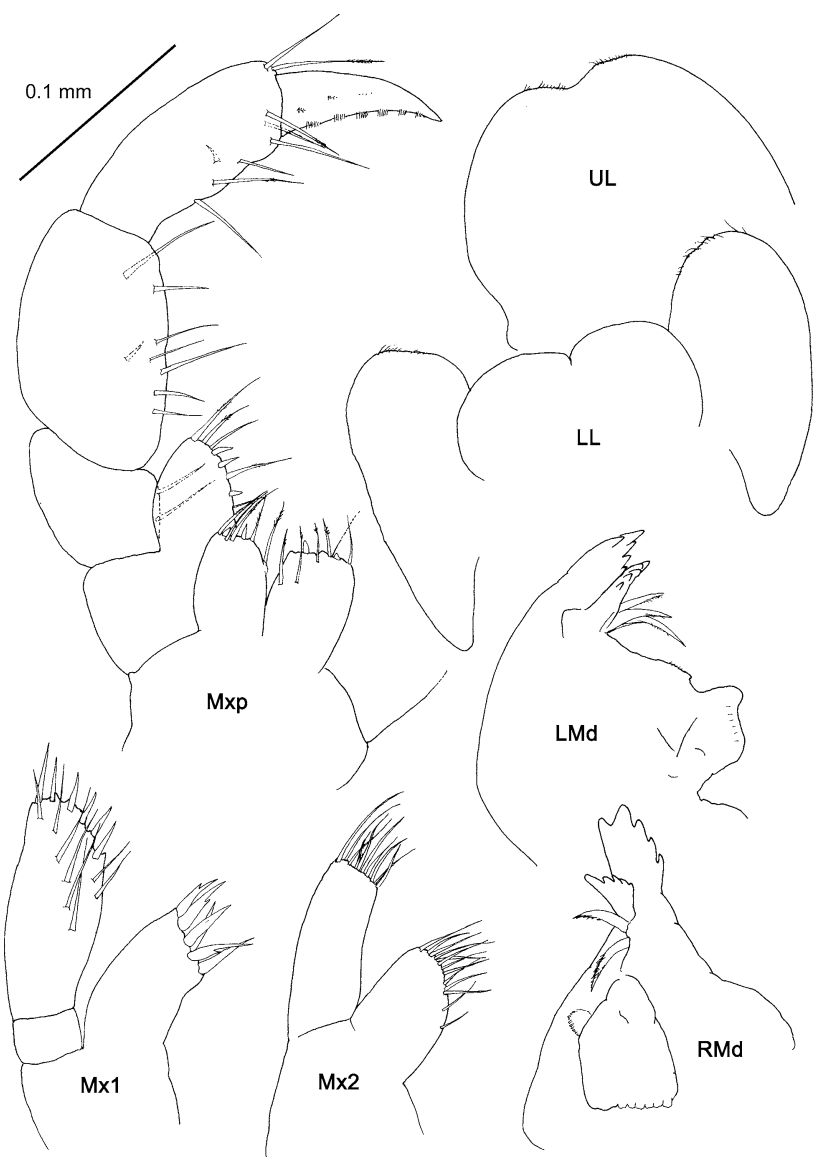

Fig. 3 Caprella tavolarensis n. sp. Mouthparts of paratype male (paratype 1, MVRCr 500.2)

Description

Holotype male (MVRCr 500.0)

Body length $5.8 \mathrm{~mm}$.

Lateral view (Fig. 2). Head with a short rostrum (almost absent in subadult males), suture between head and pereonite 1 present. Body dorsally smooth, without tubercles. A pair of anterolateral projections on pereonites 2,3 and 4 .

Gills (Fig. 2). Present on pereonites 3-4, elongate, length about twice width.

Mouthparts (Fig. 3, figured from paratype 1). Upper lip symmetrically bilobed, small setulae apically. Mandibular molars process strong; incisor and lacinia mobilis 5-toothed; left mandible with three pectinated setae, right mandible with only two; small molar flake present on right mandible. Lower lip with inner lobes poorly demarcated and outer lobes scarcely setose. Maxilla 1 outer lobe with six robust and stout setae; distal article of palp with 


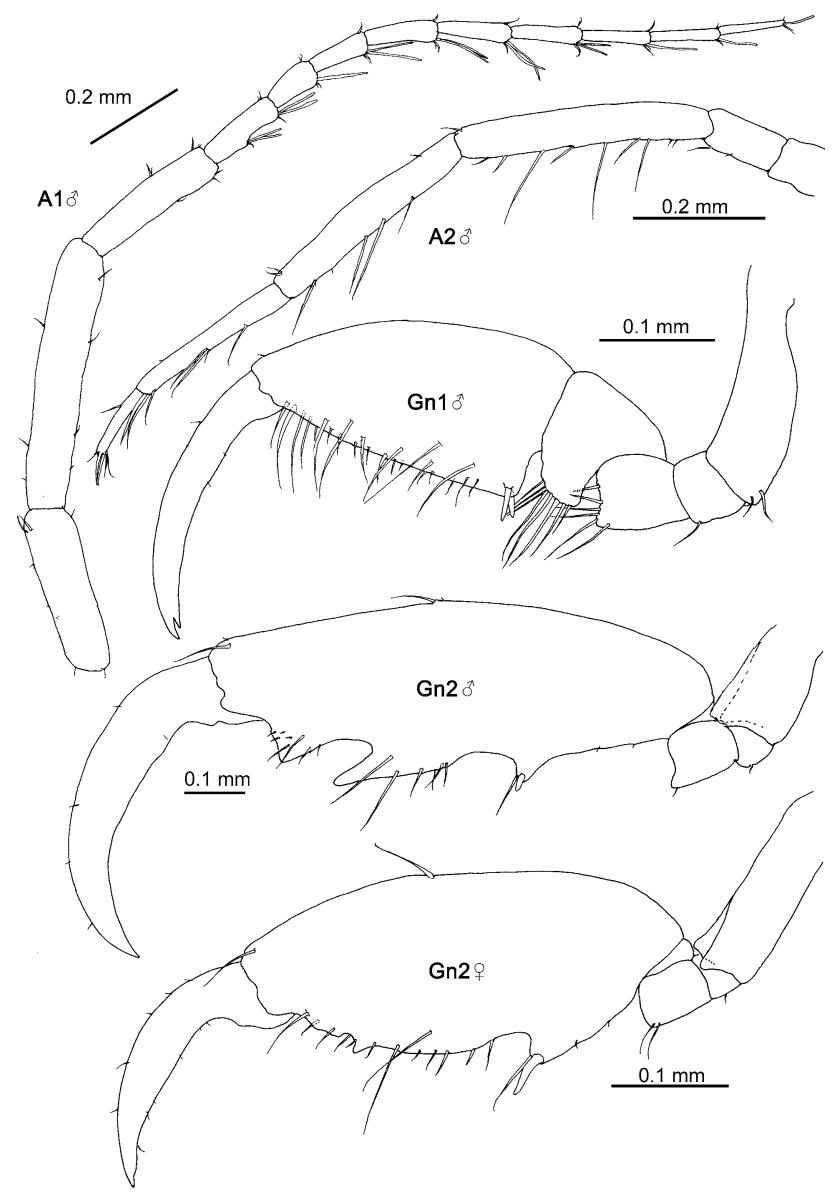

Fig. 4 Caprella tavolarensis n. sp. Male holotype (MVRCr 500.0) antenna 1, antenna 2 and gnathopods 1 and 2. Female paratype (MVRCr 500.1) gnathopod 2

six setae distally and eight lateral setae. Maxilla 2 inner lobe oval and outer lobe rectangular, about 1.5 times as long as the inner lobe. Maxilliped inner plate with three robust and short setae (similar to "teeth") and five plumose setae; outer plate with long, plumose setae and three robust setae (like "teeth"); palp four-articulate, with long plumose setae, article 4 with rows of setulae on its grasping margin.

Antennae (Fig. 4). Antenna 1 about half of the body length; peduncle scarcely setose; flagellum 9-articulate. Antenna 2 flagellum two-articulate, with scarce setae; swimming setae absent.

Gnathopods (Fig. 4). Gnathopod 1 basis as long as ischium, merus and carpus combined; propodus palm with two proximal grasping spines, grasping margin smooth; dactylus elongate. Gnathopod 2 inserted near distal end of pereonite 2; basis short, about one-sixth of pereonite 2 in length, provided with a ventral projection and lacking serrate carina; propodus elongate, length about 3 times width; palm concave with one proximal projection provided with grasping spine; another projec-

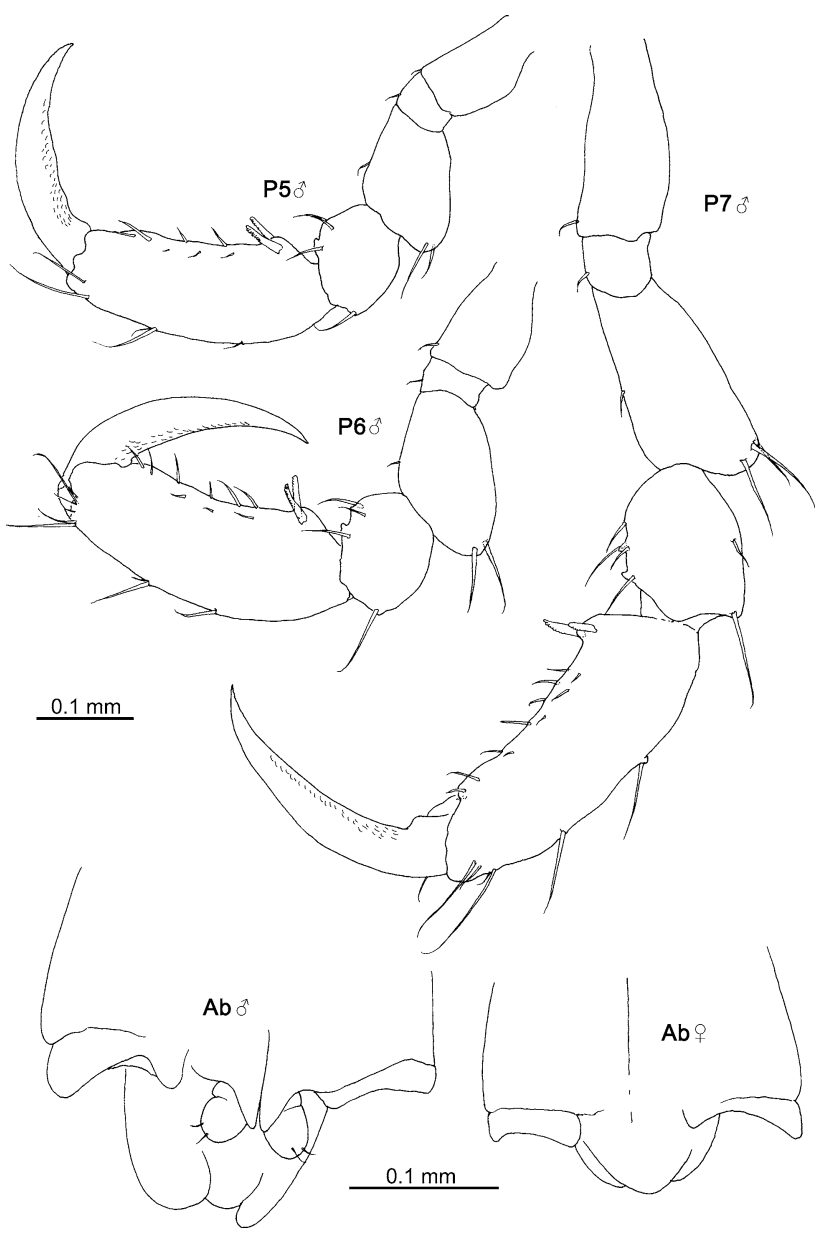

Fig. 5 Caprella tavolarensis n. sp. Pereopods 5-7 and abdomen of male paratype (paratype 1, MVRCr 500.2). Abdomen of female paratype (paratype 4, MVRCr 500.5)

tion one-quarter length from distal end, followed by "U" notch distally.

Pereopods (Fig. 5, figured from paratype 1). Pereopods 3 and 4 absent. Pereopod 5, 6 and 7 increasing in length; basis without serrate carina; carpus of pereopod 5 and 6 with an inner tooth, and pereopod 7 with two teeth; propodus provided with a pair of grasping spines proximally.

Penes (Fig. 5). Short, length about 1.2 times the width. Abdomen with a pair of two-articulate appendages, a pair of lateral lobes and a single dorsal lobe.

\section{Paratype female (MVRCr 500.1)}

Body length $3.5 \mathrm{~mm}$. Similar to male, except for the following characters: flagellum of antenna 1 eight-articulate (Fig. 2); oostegites present (Fig. 2), being slightly setose on pereonite 3; gnathopod 2 (Fig. 4) inserted on the anterior half of pereonite 2 , basis about one-fourth of pereonite 2 in length, length of propodus about 2 times width, U-notch 
Fig. 6 Scanning electron microscopy (SEM) pictures of Caprella tavolarensis $\mathrm{n}$. $\mathrm{sp}$. male adults. a Head region with antennae, mouthparts and gnathopods 1, lateral view. b Head and pereonites 1-4 with gnathopods 1, 2 and gills, lateral view; large male length: $6.1 \mathrm{~mm}$. c Head region with mouthparts and insertion of gnathopods 1 , lateral view. d Mouthparts with maxilliped, ventral view. e Maxilliped, lateral view. f Maxilliped dactylus outer margin
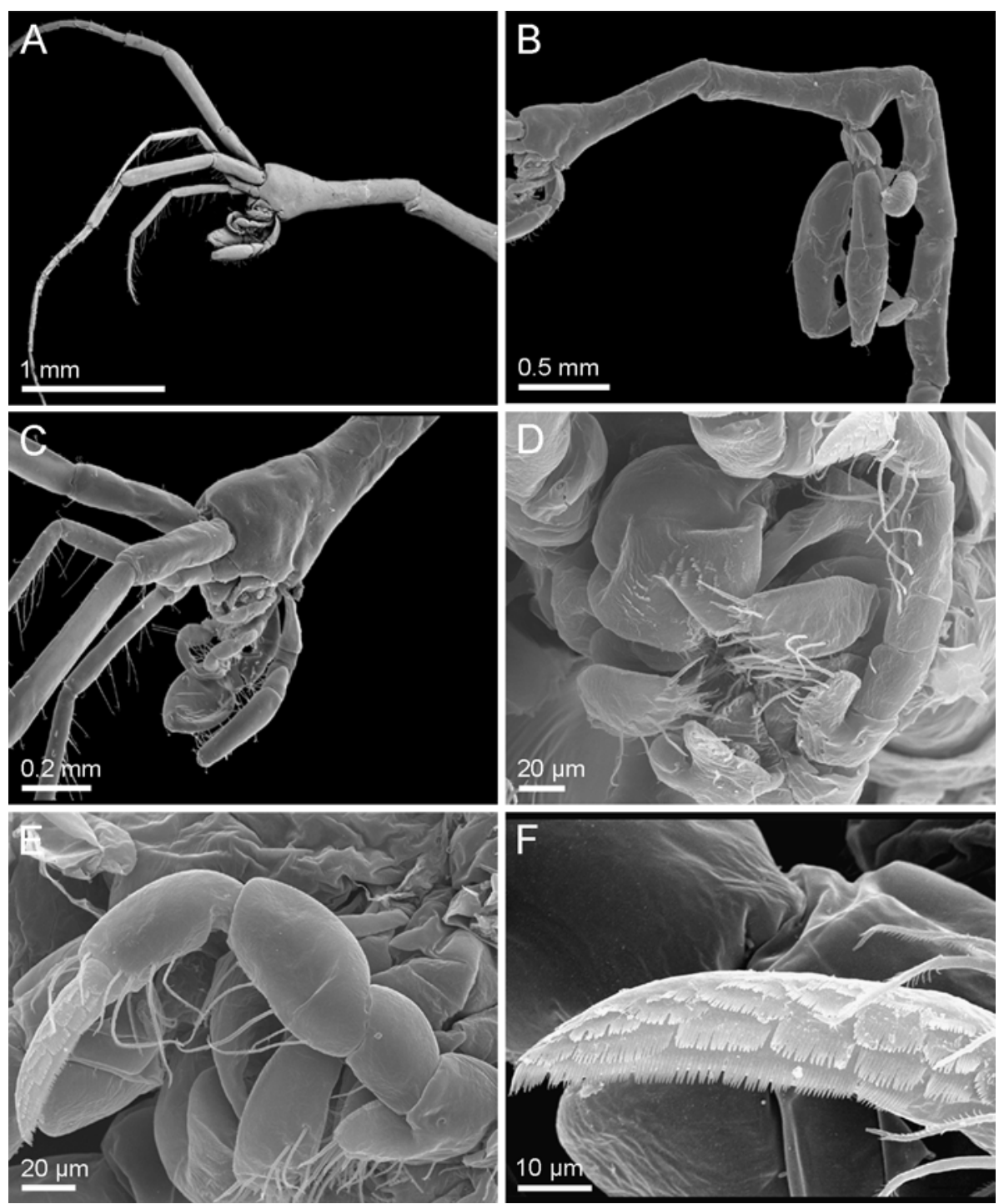

lacking; abdomen without appendages, only the lateral lobes and dorsal lobe present.

\section{Intraspecific variation}

Length varied from 2.8 to $6.3 \mathrm{~mm}$ (males) and $2.0-4.3 \mathrm{~mm}$ (females). Most of the morphological characters studied in the present paper were rather constant. All the specimens examined had the body smooth dorsally, lacking tubercles. The rostrum was very short in both males and females, being extremely reduced (almost absent) in subadult specimens. Insertion of gnathopod 2 was near distal end of pereonite 2 , although the insertion could vary from half to distal end of pereonite 2, depending on the maturation stage of the specimen. Length of pereonite 1 and 2 vary also according to the stage of development (Figs. 6b, 8d). All the specimens were lacking serrate carina on the basis of gnathopod 2 and basis of pereopods. Carpus of pereopods 5-7 was provided by tiny teeth (Figs. 7f, 9e), although the number of these internal teeth could vary between 1 and 3. Six paratype specimens ( 3 males and 3 females) were dissected for examination of mouthparts. The structure of mouthparts is very constant, except for the following: (a) the number of strong setae (similar to "teeth") in the outer lobe of the maxilliped could vary between 1 and 3; (b) the number of lateral setae of distal article of the palp of maxillae varied also from 4 to 8 .

\section{Ecological remarks}

The specimens of Caprella tavolarensis n. sp. were collected from a well-preserved Posidonia oceanica bed between 10 and $15 \mathrm{~m}$ depth, located in a totally protected area. The meadow under investigation occurs on sandy bottoms and granitical rocks, and extends to a lower limit of about $27-30 \mathrm{~m}$ in depth. At sampling depth, mean meadow 
Fig. 7 SEM pictures of Caprella tavolarensis $\mathrm{n}$. sp. male adults, lateral views. a Gnathopod 1 and maxilliped. b Gnathopods 2. c Basis of gnathopods 2 with projections. d Pereonites 3-4 with gills. e Pereopod 5. f Pereopod 6 carpus with acute teeth
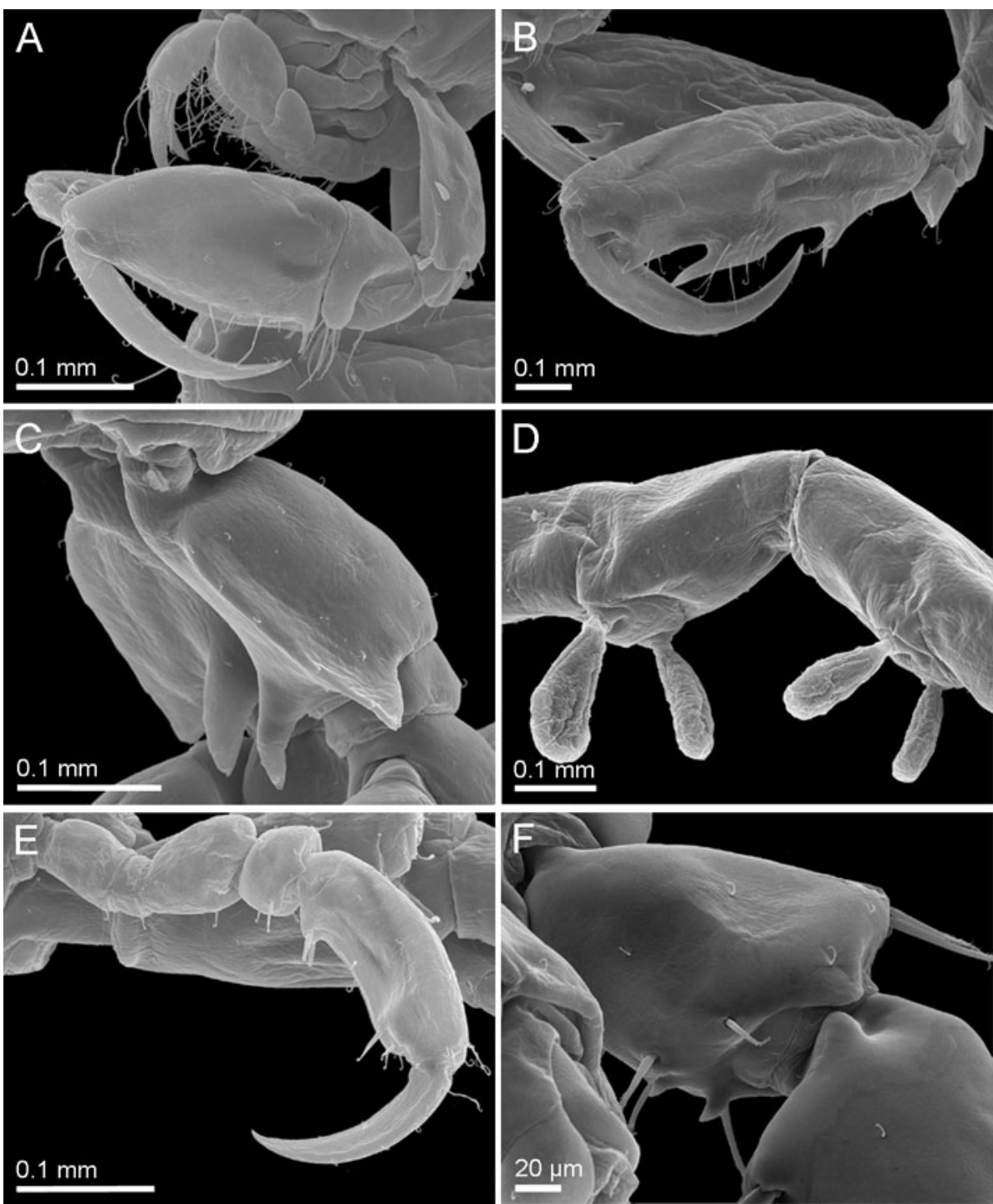

density reached $259 \pm 98$ shoots $\mathrm{m}^{-2}$ (mean \pm standard deviation of 16 measurements).

The amphipod fauna of this meadow is dominated by the species Caprella tavolarensis n. sp. (37.2\%), Apherusa chiereghinii Giordani-Soika (17.4\%), Aora spinicornis Afonso (12.1\%) and Phtisica marina Slabber (11.3\%). Caprella tavolarensis mean density was $64 \pm 75$ individuals $\mathrm{m}^{-2}$ (mean \pm standard deviation of 16 samples) and reached maximum density of 271 individuals $\mathrm{m}^{-2}$. The examination of horizontal spatial variability patterns, using a hierarchical nested design with spatial scales ranging from metres to hundred of metres, revealed that $C$. tavolarensis density exhibited the larger variation at the small spatial scale ( $\sim 1 \mathrm{~m})$. Although the existence of small-scale patchiness in density within $P$. oceanica meadows has long been recognised (Panayotidis et al. 1981), no correlation has been found between $C$. tavolarensis abundance and meadow density. Previous studies revealed that there is no correlation between parameters of the vagile fauna such as number of individuals and features of the $P$. oceanica meadow such as density (Scipione et al. 1996). In the same area, several experiments dealing with fish predation have been conducted. This species is little predated in comparison with other accompanying species such as Caprella acanthifera. Probably, the small size could let the specimens camouflaged among Posidonia leaves and escape from predators. Three caprellid species were found living in $P$. oceanica bed together with Caprella tavolarensis: Caprella acanthifera, Phtisica marina and Pseudoprotella phasma.

\section{Discussion}

The new species Caprella tavolarensis n. sp. is close to Caprella liparotensis Haller, 1879, and Caprella wirtzi Krapp-Schickel and Takeuchi 2005. Caprella liparotensis 
Fig. 8 SEM pictures of Caprella tavolarensis $\mathrm{n}$. sp. male adults. a Abdomen, ventral view. b Abdomen, ventroposterior view. c Detail of penes and abdominal appendages, ventral view. d Head and pereonites 1-2 with gnathopods 1, 2, lateral view; young male length: $3.6 \mathrm{~mm}$
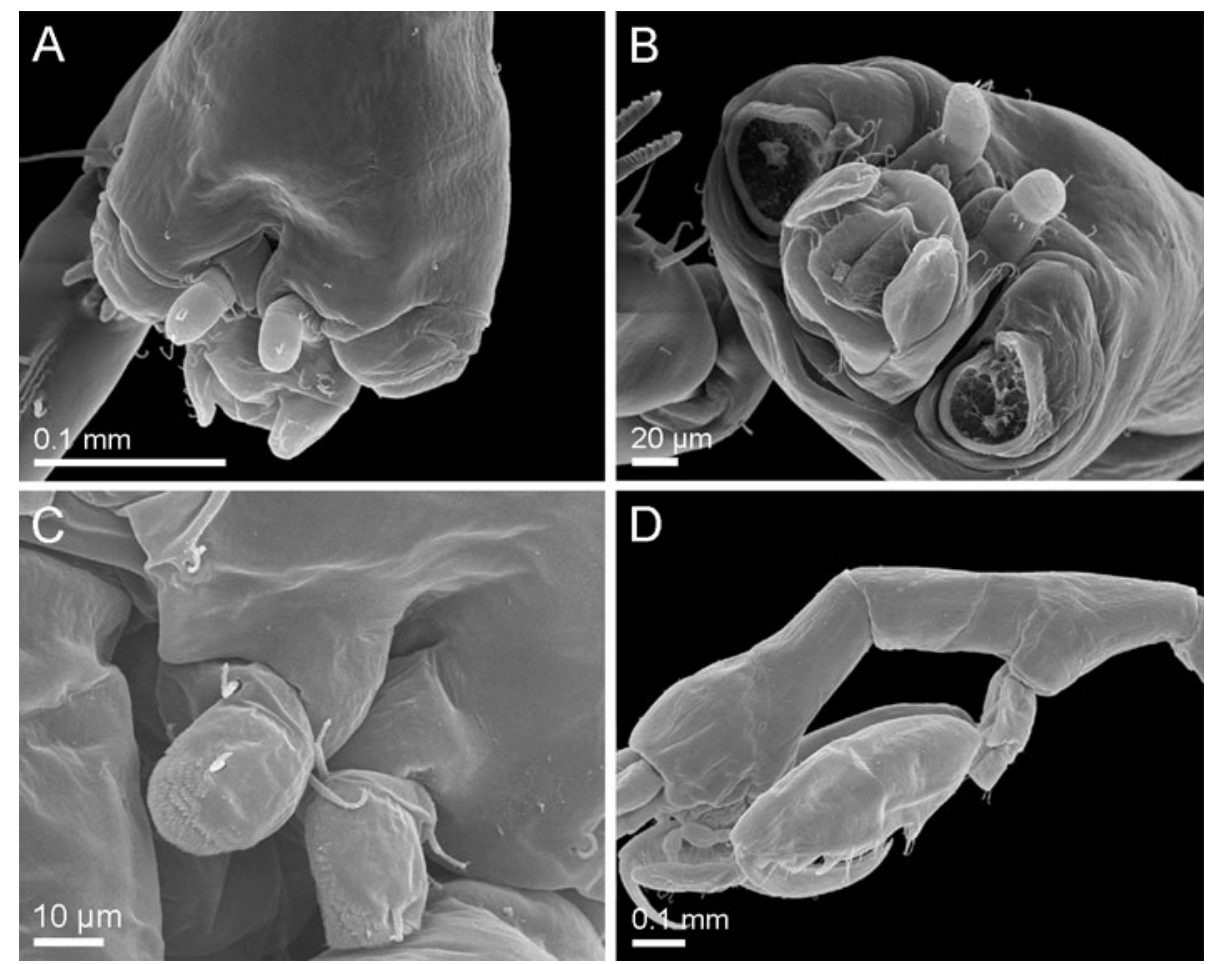

was described based on specimens collected from Lipari, Italy and has since been reported from Portugal to the whole Mediterranean, including the Adriatic and Black Seas (Krapp-Schickel and Takeuchi 2005). Additional descriptions of this species have been provided by Chevreux and Fage (1925), Krapp-Schickel (1993) and GuerraGarcía and Takeuchi (2002). Krapp-Schickel and Takeuchi (2005) described Caprella wirtzi from Cape Verde Islands (Atlantic), close to $C$. liparotensis, but showing differences on antenna 2, gnathopod 2 and pereonites.

The new species Caprella tavolarensis clearly differs from $C$. liparotensis and $C$. wirtzi on the following characters: (1) smaller size in $C$. tavolarensis (males 3-6 mm, females 2-4 mm) than in C. liparotensis (males 7-12 $\mathrm{mm}$, females 4-7 mm) and $C$. wirtzi (males $8-12 \mathrm{~mm}$, females 4-6 mm); (2) body more elongate and dorsally smooth in C. tavolarensis, while dorsal tubercles or acute projections are present on pereonites 5-7 on the other two species; (3) very short rostrum in $C$. tavolarensis, while well developed in $C$. liparotensis and $C$. wirtzi; (4) maxilliped less setose in C. tavolarensis; (5) peduncle articles 2 and 3 of antenna 1 lacking dense setae in C. tavolarensis; (6) antenna 2 lacking swimming setae in C. tavolarensis; (7) basis of gnathopod 2 and pereopods lacking serrate carina in $C$. tavolarensis and $C$. wirtzi, while a developed serration is present in C. liparotensis.

The elongate shape of the body together with the scarcely setose antennae and very short rostrum make C. tavolarensis to resemble the species Caprella mitis and
C. paramitis. However, the gnathopod 2 is totally different in these species.

Based on the considerable degree of intraspecific morphological variation in C. liparotensis, Krapp-Schickel and Takeuchi (2005) already doubted about the wide distribution of $C$. liparotensis within the Mediterranean and northeast Atlantic and pointed out that careful checking of rich series taken from many different localities should shed more light on what is variable and what are small but constant differences. Probably, the new species described in the present paper may have been misidentified as $C$. liparotensis in the past. So far, $C$. liparotensis had been recorded from different species of algae and hydroids (Krapp-Schickel 1993; Guerra-García 2001; Guerra-García and Takeuchi 2002), and also from $P$. oceanica seagrass beds (Scipione and Fresi 1984; Zakhama-Sraieb et al. 2006). The most common caprellid species recorded from seagrasses at Mediterranean sites are Caprella acanthifera Leach, 1814, Caprella rapax Mayer, 1890, Phtisica marina Slabber, 1769, Pseudoprotella phasma Montagu, 1804 and Pariambus typicus Krøyer, 1844 (Scipione 1998; Sánchez-Jerez et al. 1999; Luque et al. 2004; González et al. 2008). However, these caprellid species are not exclusive of these habitats since they have been collected from many different substrates (Guerra-García 2001). During the present study, the new species Caprella tavolarensis was found together with Caprella acanthifera, Pseudoprotella phasma and Phtisica marina. Probably, further studies on Posidonia oceanica beds of other Mediterranean areas could reveal 
Fig. 9 SEM pictures of Caprella tavolarensis $\mathrm{n}$. sp. female adults. a Entire animal, lateral view. b Entire animal, ventral view. c Gnathopod 2, lateral view. d Pereonites 5-6 showing genital papillae on pereonite 5 , ventral view. e Pereopod 5, lateral view. f Oostegites and gills, lateral view
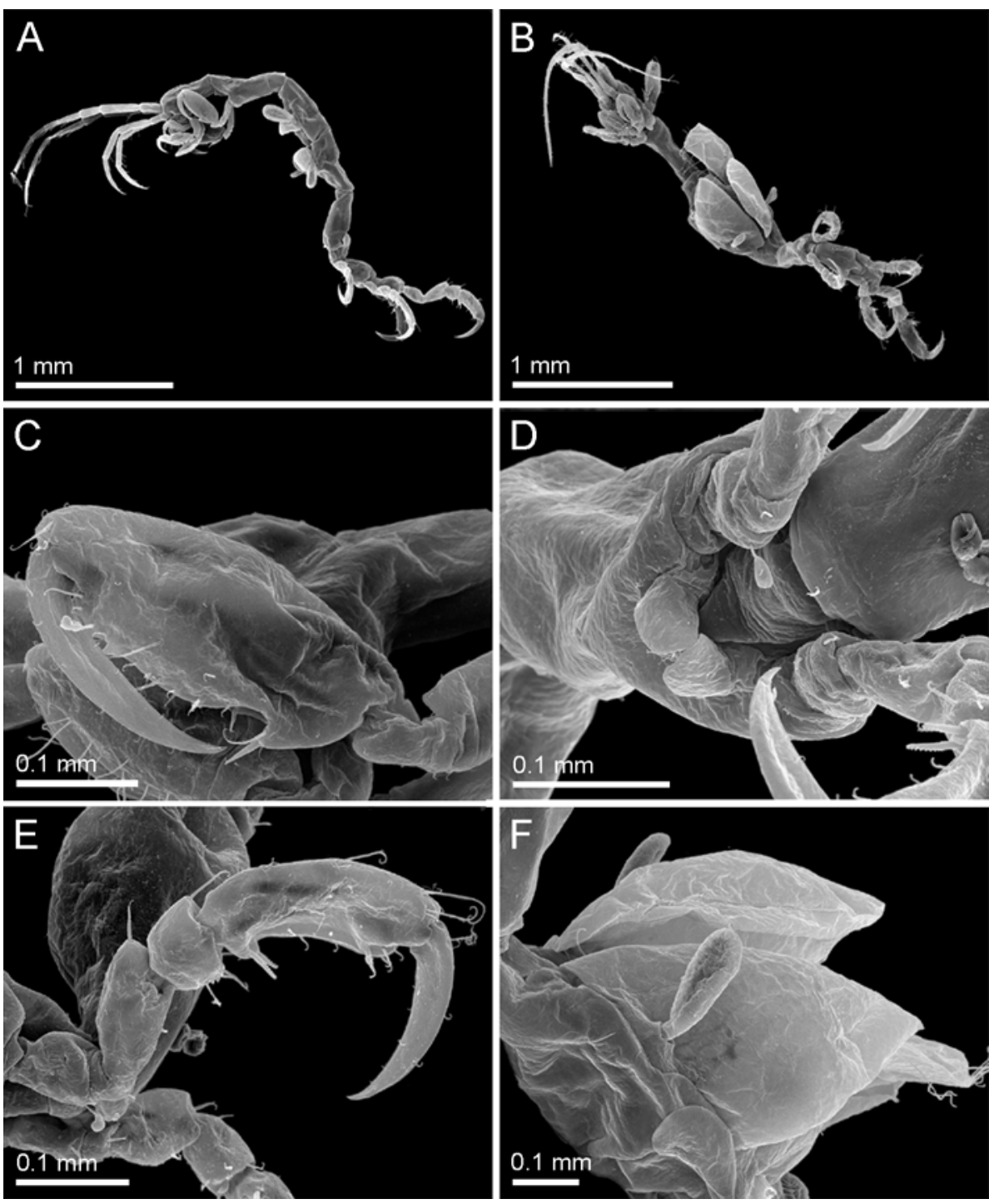

the presence of $C$. tavolarensis, although we cannot exclude that the species could be an endemism of the area, and this would explain that the species has not been reported so far in the Mediterranean. Monitoring of the amphipod fauna in other comparable partially protected localities (B and C zones) of the Tavolara-Punta Coda Cavallo Marine Protected Area (Fig. 1) showed that specimens of Caprella tavolarensis have been found in only very rare cases, while it is the dominant species in the A zone with $37.2 \%$ of the total amphipod fauna. We cannot exclude a possible role of the protection status of this locality, highlighting the importance of totally protected areas in species conservation.

So far, 41 caprellid species have been recorded at the Mediterranean Sea (Table 1). Krapp-Schickel (1993) included 23 species in her revision. After these, several taxa were described, especially from the Strait of Gibraltar area, doubling the number of species included in the monographs edited by the late Sandro Ruffo. Caprella scaura Templeton, 1836 has also been recorded recently from the Mediterranean as invader species (Krapp et al. 2006). Most species $(51 \%)$ have been collected only in Mediterranean waters and can be considered Mediterranean endemic so far (Table 1), with many species restricted to the Strait of Gibraltar area. Bellan-Santini and Ruffo (1998) reported $37 \%$ of amphipod species endemic to the Mediterranean Sea. Consequently, more caprellid studies are needed since, probably, further researches along the Atlantic Coast of North Africa and the Iberian Peninsula would likely reduce the number of caprellids that are considered endemic to the Mediterranean. It is the case, for example, of Caprella rapax and Parvipalpus major, which have been collected recently on the Atlantic Iberian coast (see Guerra-García and Takeuchi 2002). Although Caprella grandimana and C. hirsuta have also been reported from nearby areas of the Atlantic side of the Strait of Gibraltar (Bellan-Santini and 
Table 1 Caprellids cited in Mediterranean waters

\begin{tabular}{|c|c|}
\hline Name of species & Distribution \\
\hline Caprella acanthifera Leach, 1814 & $\mathrm{M}, \mathrm{A}$ \\
\hline Caprella andreae Mayer, 1890 & $\mathrm{M}, \mathrm{A}, \mathrm{P}$ \\
\hline Caprella caulerpensis Guerra-García, Sánchez-Moyano and García-Gomez, 2002 & $\mathrm{E}^{*}$ \\
\hline Caprella cavediniae Krapp-Shickel and Vader, 1998 & $\mathrm{E}$ \\
\hline Caprella ceutae Guerra-García and Takeuchi, 2002 & $\mathrm{E}^{*}$ \\
\hline Caprella danilevskii Czerniavski, 1868 & $\mathrm{M}, \mathrm{A}, \mathrm{P}, \mathrm{I}$ \\
\hline Caprella dilatata Krøyer, 1843 & $\mathrm{M}, \mathrm{A}$ \\
\hline Caprella equilibra Say, 1818 & $\mathrm{M}, \mathrm{A}, \mathrm{P}, \mathrm{I}$ \\
\hline Caprella erethizon Mayer, 1901 & $\mathrm{M}, \mathrm{A}$ \\
\hline Caprella fretensis Stebbing, 1878 & $\mathrm{M}, \mathrm{A}$ \\
\hline Caprella grandimana Mayer, 1882 & $\mathrm{E}$ \\
\hline Caprella hirsuta Mayer, 1890 & $\mathrm{E}$ \\
\hline Caprella lilliput Krapp-Shickel and Ruffo, 1987 & $\mathrm{E}$ \\
\hline Caprella linearis Linnaeus, 1767 & $\mathrm{M}, \mathrm{A}$ \\
\hline Caprella liparotensis Haller, 1879 & $\mathrm{M}, \mathrm{A}$ \\
\hline Caprella mitis Mayer, 1890 & $\mathrm{E}$ \\
\hline Caprella monai Guerra-García, Sánchez-Moyano and García-Gómez, 2001 & $\mathrm{E}^{*}$ \\
\hline Caprella paramitis Guerra-García, Sánchez-Moyano and García-Gómez, 2001 & $\mathrm{E}^{*}$ \\
\hline Caprella penantis Leach, 1840 & $\mathrm{M}, \mathrm{A}, \mathrm{P}, \mathrm{I}$ \\
\hline Caprella pseudorapax Guerra-García, Sánchez-Moyano and García-Gómez, 2001 & $\mathrm{E}^{*}$ \\
\hline Caprella rapax Mayer, 1890 & $\mathrm{M}, \mathrm{A}$ \\
\hline Caprella sabulensis Guerra-García, Sánchez-Moyano and García-Gómez, 2001 & $\mathrm{E}^{*}$ \\
\hline Caprella santosrosai Sánchez-Moyano, Jiménez-Martín and García-Gómez, 1995 & $\mathrm{E}^{*}$ \\
\hline Caprella scaura Templeton, 1836 & $\mathrm{M}, \mathrm{A}, \mathrm{P}, \mathrm{I}$ \\
\hline Caprella takeuchii Guerra-García, Sánchez-Moyano and García-Gómez, 2001 & $\mathrm{E}^{*}$ \\
\hline Caprella tavolarensis n.sp. & $\mathrm{E}$ \\
\hline Caprella telarpax Mayer, 1890 & $\mathrm{E}$ \\
\hline Caprella tuberculata Bate and Westwood, 1868 & $\mathrm{M}, \mathrm{A}$ \\
\hline Caprella sp (armata-group) (see Krapp-Shickel and Vader, 1998) & $\mathrm{M}, \mathrm{A}$ \\
\hline Deutella schieckei Cavedini, 1982 & $\mathrm{E}$ \\
\hline Liropus elongatus Mayer, 1890 & $\mathrm{E}$ \\
\hline Liropus minimus Mayer, 1890 & $\mathrm{E}$ \\
\hline Pariambus typicus Krøyer, 1844 & $\mathrm{M}, \mathrm{A}$ \\
\hline Parvipalpus linea Mayer, 1890 & $\mathrm{M}, \mathrm{A}$ \\
\hline Parvipalpus major A. Carausu, 1941 & $\mathrm{M}, \mathrm{A}$ \\
\hline Pedoculina bacescui A. Carausu, 1940 & $\mathrm{E}$ \\
\hline Pedoculina garciagomezi Sánchez-Moyano, Carballo and Estacio, 1995 & $\mathrm{E}^{*}$ \\
\hline Phtisica marina Slabber, 1769 & $\mathrm{M}, \mathrm{A}, \mathrm{P}$ \\
\hline Pseudolirius kroyerii Haller, 1879 & $\mathrm{E}$ \\
\hline Pseudoprotella inermis Chevreux, 1927 & $\mathrm{M}, \mathrm{A}$ \\
\hline Pseudoprotella phasma Montagu, 1804 & $\mathrm{M}, \mathrm{A}$ \\
\hline
\end{tabular}

Modified from Guerra-García and Takeuchi (2002)

$E$ Mediterranean endemic; $M$ Mediterranean Sea; $A$ Atlantic Ocean; $P$ Pacific Ocean; I Indian Ocean

* Indicates that the species has a restricted distribution area to the Strait of Gibraltar
Caprella erethizon, C. fretensis or Caprella tuberculata, typically distributed along the North Atlantic, have been recently collected at the Mediterranean side of the Strait of Gibraltar.

Summarising, in spite of the amphipod fauna from the Mediterranean can be considered as very well studied, still new species are being described. Further sampling, especially 
from sediments, maerl bottoms and corraligène (below $40-50 \mathrm{~m}$ ) should be conducted to complete our knowledge about Mediterranean caprellids.

Acknowledgments We are very grateful to A. Navone and P. Panzalis (Consorzio di Gestione Area Marina Protetta Tavolara-Punta Coda Cavallo, Olbia, Italy) for their hospitality and field assistance. Many thanks to A. Pérez-Perera for valuable help during field work. Thanks are also due to G. Lepoint and S. Gobert for their help in advices and the staff of the Laboratoire d'Océanologie (Université de Liège, Belgium), as well as P. Compère for help and advices with SEM pictures (Laboratoire de Morphologie Fonctionnelle et Evolutive, Université de Liège). This study was supported by the Belgian Fund for Research for the Industry and Agriculture (FRIA, grant nr. FC77010), by a Special Research Fund of the University of Liège (FSR) and by the Belgian National Fund for Scientific Research (FNRS: FRFC 2.4.502.08.F). Additional financial support of this work was provided by the Ministerio de Educación y Ciencia (Project CGL2007-60044/BOS) co-financed by FEDER funds, by the Consejería de Innovación, Ciencia y Empresa, Junta de Andalucía (Project P07-RNM-02524). This paper is MARE publication number 205.

\section{References}

Bellan-Santini D, Ruffo S (1998) Faunistics and zoogeography. In: The Amphipoda of the Mediterranean (Ed S Ruffo). Mém Inst Océan, vol 13, no 4, pp 895-911

Buia MC, Gambi MC, Zupo V (2000) Structure and functioning of Mediterranean seagrass ecosystems: an overview. Biol Mar Medit 7(2):167-190

Chevreux E, Fage L (1925) Amphipodes. Faune de France 9:1-488

Edgar GJ, Shaw C, Watson GF, Hammond LS (1994) Comparison of species richness, size-structure and production of benthos in vegetated and unvegetated habitats in Western Port, Victoria. J Exp Mar Biol Ecol 176:201-226

González AR, Guerra-García JM, Maestre MJ, Ruiz-Tabares A, Espinosa F, Gordillo I, Sánchez-Moyano JE, García-Gómez JC (2008) Community structure of caprellids (Crustacea: Amphipoda: Caprellidae) on seagrasses from southern Spain. Helgol Mar Res 62:189-199

Guerra-García JM (2001) Habitat use of the Caprellidea (Crustacea: Amphipoda) from Ceuta, North Africa. Ophelia 55:27-38

Guerra-García JM, Ros M, Gordillo I, Cabezas MP, Baeza-Rojano E, Izquierdo D, Corzo J, Domínguez J, Varona S (2010) Distribution patterns of intertidal and shallow water caprellids associated with macroalgae along the Iberian Peninsula. Zoologica Baetica 21:101-129

Guerra-García JM, Takeuchi T (2002) The Caprellidea (Crustacea: Amphipoda) from Ceuta, North Africa, with the description of three species of Caprella, a key to the species of Caprella, and biogeographical discussion. J Nat Hist 36:675-713

Ito A, Wada H, Aoki MN (2008) Phylogenetic analysis of caprellid and corophioid amphipods (Crustacea) based on the 18S rRNA gen, with special emphasis on the phylogenetic position of the Phtisicidae. Biol Bull 214:176-183

Krapp T, Lang C, Libertini A, Melzer RR (2006) Caprella scaura Templeton, 1836 sensu lato (Amphipoda: Caprellidae) in the Mediterranean. Org Div Evol 6:77-81

Krapp-Schickel T (1993) Suborder Caprellidea. In: the Amphipoda of the Mediterranean (Ed S Ruffo). Mém Inst Océan, vol 13, no 3, pp 773-809
Krapp-Schickel T, Takeuchi I (2005) A new species of Caprella (Amphipoda: Caprellidae) from the Cape Verde Islands (Atlantic), with note on the Mediterranean Caprella liparotensis. J Mar Biol Ass UK 85:93-100

Larkum AWD, McComb AJ, Shepherd SA (1989) Biology of seagrasses. A treatise on the biology of seagrasses with special reference to the Australian region. Elsevier Science Publication, Amsterdam

Laubitz D (1993) Caprellidea (Crustacea: Amphipoda): towards a new synthesis. J Nat Hist 27:965-976

Luque AA, Templado J, Barrajón A, Cuesta S, González M, Larrad A, López E, Ortiz M, López de la Cuadra CM, López PJ, Remón JM, Moreno D (2004) Apéndice. La diversidad faunística de las praderas de Posidonia oceanica de Almería. In: Luque AA, Templado J (eds) Praderas y bosques marinos de Andalucía, pp 273-282. Consejería de Medio Ambiente, Junta de Andalucía, Sevilla, p 336

Michel L, Lepoint G, Dauby P, Sturaro N (2010) Sampling methods for amphipods of Posidonia oceanica meadows : A comparative study. Crustaceana 83(1):39-47

Myers AA, Lowry JK (2003) A phylogeny and a new classification of the Corophiidea Leach, 1814 (Amphipoda). J Crust Biol 23:443485

Nakamura Y, Sano M (2005) Comparison of invertebrate abundance in a seagrass bed and adjacent coral and sand areas at Amitori Bay, Iriomote Island, Japan. Fish Sci 71:543-550

Panayotidis P, Boudouresque CF, Marcot-Coqueugniot J (1981) Microstructure de l'herbier de Posidonia oceanica (Linnaeus) Delile. Bot Mar 24(3):115-124

Pranovi F, Curiel D, Rismondo A, Marzocchi M, Scattolin M (2000) Variations of the macrobenthic community in a seagrass transplanted area of the Lagoon of Venice. Sci Mar 64:303-310

Sánchez-Jerez P, Barberá Cebrián B, Ramos Esplá AA (1999) Comparison of the epifauna spatial distribution in Posidonia oceanica, Cymodocea nodosa and unvegetated bottoms: Importance of meadow edges. Acta Oecologica 20(4):391-405

Scipione MB (1998) Amphipod biodiversity in the foliar stratum of shallow-water Posidonia oceanica beds in the Mediterranean Sea. In: FR Schram and JC von Vaupel Klein (ed) Proceedings of the fourth Crustacean congress, Crustaceans and the Biodiversity Crisis, Koninklije Brill NV, Leiden: 649-662

Scipione MB, Fresi E (1984) Distribution of amphipod crustaceans in Posidonia oceanica (L.) Delile foliar stratum. In: Boudouresque CF, Jeudy de Grissac A, Olivier J (ed) International workshop on Posidonia oceanica beds, GIS Posidonie publication, France, 319-329

Scipione MB, Gambi MC, Lorenti M, Russo GF, Zupo V (1996) The vagile fauna of the leaf stratum of Posidonia oceanica and Cymodocea nodosa in the Mediterranean Sea. In: Kuo J, Phillips RC, Walker DI, Kirkman H (eds) Seagrass biology. The University of Western Australia, Perth, pp 249-260

Takeuchi I (1993) Caprella arimotoi, a new species (Crustacea: Amphipoda: Caprellidea) from the Seto Inland Sea, Japan. Proc Biol Soc Wash 106:115-121

Templado J (2004) Las praderas de fanerógamas marinas. Introducción. In: Luque AA, Templado J (eds) Praderas y bosques marinos de Andalucía. Consejería de Medio Ambiente, Junta de Andalucía, Sevilla, pp 57-59

Zakhama-Sraieb R, Sghaier Y-R, Charfi-Cheikhrouha F (2006) Is amphipod diversity related to the quality of Posidonia oceanica beds? Biol Mar Medit 13(4):174-180 